\title{
Indonesian Multicultural Politic: Building Political Citizenship in Democracy in Majanggut I Village Kerajaan Regency, Pakpak Bharat District, North Sumatra Province
}

\author{
Budi Ali Mukmin ${ }^{1}$. Prayetno ${ }^{2}$. Halking ${ }^{3} \cdot$ Hulman Sinamo ${ }^{4}$. Ismo ${ }^{5}$ \\ \{bamsarumpaet@gmail.com¹. eno.pray@gmail.com². halkingsamawa@gmail.com ${ }^{3}$. \\ sinamo2hulman@gmail.com ${ }^{4}$. ismoantonius98@gmail.com ${ }^{5}$ \} \\ Department of Civic Education, Universitas Negeri Medan, Indonesia
}

\begin{abstract}
This research aims to see how the process of democratization in Majanggut I Village, Kerajaan District, Pakpak Bharat Regency when the village head election ended the chaos and resulted in the death of the injured in 2018 ago. This paper also wants to see the possibility that a model of democratic consolidation needs to be put on the aspect of the locality. Without damaging the existing democratic order, the locality-based democracy consolidation model wants to make each individual the main actor who plays the political role of citizenship so that they can create a democratic model that adopts from its cultural values. The method used in this research uses the descriptive qualitative method. The use of fieldwork with the observation method was carried out in this study. In addition to observation, the interview method was also carried out both to the Village Government, Majanggut I, and to the village community. In addition to interviews, various kinds of documentation and literature studies were also used to strengthen and sharpen the results of this study. The results showed that Majanggut I villagers' understanding of democracy was still limited to the conception of political contestation. Opportunities for locality values to be accommodated in a democracy are very open, even though the values of locality in the village are fading away. The Citizenship Politics in Majanggut I Village has not placed citizens as actors of democracy itself. The people of Majanggut I village are still the objects of democracy itself. This indication can be seen from the lack of participation of the village community in the development process in the village and the process of political development, including in the contestation of village head elections.
\end{abstract}

Keywords: Citizenship Politics, Democratic Consolidation, Political Contestation, Village Head Election

\section{Introduction}

Citizenship Politics in North Sumatra is a topic that will be discussed in this research. Maintaining the consolidation of democracy amid the high level of cultural, religious and ethnic diversity in North Sumatra is not an easy matter to implement. A political integration formula is 
needed to combine the demands of unity and diversity. The liberal democracy that developed at this time was understood differently by the people in North Sumatra because it was given through a state-centric mechanism. Indications of different meanings of democracy can be seen from the case of village head elections held simultaneously in North Sumatra in 2018. Election of Majanggut II village chiefs in the Royal District, Pakpak Bharat Regency ended in the chaos which resulted in the fall of dozens of injured victims. This conflict affected the power vacuum in the village of Majanggut II because the Pakpak Bharat Regent was reluctant to appoint the elected village head on 25 February 2019 ago. The same thing also happened with the election of the village head of Purbatua, North Barus Subdistrict, Tapanuli Tengah District which also ended in chaos with the incident of confiscation of the C6 file on the table of the Village Head Election Committee and the ballot box seizure. Ironically, the confiscation of the file and ballot box is done openly in public. Villages in North Sumatra, which have been known to have a solid local wisdom system, are not very capable as mediators of the emergence of various conflicts in democratic practices.

The political significance of citizenship to interpret democracy in North Sumatra is interesting to study because we need a new perspective to see the practice of Indonesian democracy. Specifically, this research wants to review the consolidation of democracy in North Sumatra based on aspects of the locality which can be used as an alternative model to improve the liberal democratic system that is often misinterpreted in each region. Re-setting the democratization agenda by paying attention to aspects of locality offered by Santoso[1], to see the possibility of involving citizens is the entrance to see the case in North Sumatra. With a simpler language, Santoso's ideas to be translated into democratic development are no longer imposed by the state, because each locality in Indonesia has actors with a certain style where they carry out their respective roles by establishing certain patterns of relations that uphold high values that they believe so that they involve themselves in collective action to overcome problems together [1]. The politics of citizenship can be said as a locomotive to fill the spaces of the locality that have diversity in North Sumatra. The bottom-up design of democracy will be born if the involvement of citizens has the right to determine their identity in democracy.

What happened in Majanggut I and Purbatua signaled that the process of consolidating democracy that provided spaces for public participation was rooted in different ways. Villages that have a solid local wisdom system have turned out to be unable to mediate conflicts. It is too rash to say that the spaces of democracy today destroy the existing order of locality values. However, it cannot be denied that the argument developed by savirani is also true, as an excuse to overcome the problem of democratization, many actors use the freedom that exists today to find alternative ways but does not always act democratically [2]. Kymlicka, is a figure who often becomes a reference for many people when talking about the politics of multiculturalism. Multicultural politics is not merely an appreciation of a difference. Evaluation of multicultural political practices in a country must be seen from many aspects such as; (1) how the historical amalgamation of minority groups can be integrated into the majority group, (2) how minority groups can form institutions (political, economic, cultural), (3) how minority groups get the legal certainty contained in the state constitution [3].

Referring to what Kymlica described conception to accommodate various interests in multination states as much as possible will provide some important questions for us. (1) What is the pattern to accommodate the many different interests both in terms of religion, ethnicity, culture 
and so on? Is it enough to give three distinct forms of group rights? (2) What is the pattern for resolving conflicts that occur as a result of the many interests that have not been accommodated? Of course, this is still a big question for us, especially in Indonesia [3]. The basic building concept of multiculturalism that was initiated by Kymlica was born from the concept of liberal democracy that established autonomous rights for each individual. For Kymlica an individual must be given broad freedom to live free from the shadows of fear to practice his religion, free to express cultural values of each ethnicity and have the opportunity to get access to the information they need [4]. The idea of Kymlica's approach to liberal democracy cannot be separated from his view, Stuart Mill, who said that liberal democracy starts with the opening of political liberalization.

\section{Result and discussion}

The politics of citizenship have the same breath as multicultural politics. True multicultural politics provides space for each individual to freely express the cultural values of each different identity to obtain their rights. On the other hand, the consolidation of democracy exists to accommodate cultural values and culture is then managed to become a rule of the game together, and the consolidation of democracy is successful when cultural values owned by the community can strengthen people's organizations that can accommodate all their interests. The hope is that people's organizations synergize with the state, so that the synergy results in a power structure based on agreement, constitutional rights that can be accepted collectively, the state acts fairly and impartially [4].

Hiariej and Stokke argued that the politics of citizenship is a series of interrelated struggles where it includes struggles for cultural recognition, economic and social justice, representation in certain sectors, carried out by various groups with specific issues at different scales [5]. In this case, citizenship involves the willingness and ability of citizens to be responsible for the political affairs of their government [6]. If we refer to what Berenschot and Klinken say, citizenship politics will refer to the necessity of the participation of every citizen to be involved in every activity of social, political, economic life. If we agree with that, then democracy will work well when citizens take an active and important role to keep holders of power in control [6].

Citizenship politics not only wants to restore the nature of every citizen to get his rights which include political rights, social rights, and civil rights. But far from that, the politics of citizenship want to provide spaces for citizens to determine the identity of democracy following the locality regime is one of the requirements of a consolidated democracy that was put in place by Juan Linz and Stepan. Juan Linz and Stepan suggest there are five conditions for democracy to be consolidated. First, conditions must be created for the development of civil society. Second, there must be a relatively autonomous political society. Third, in all citizens of the national territory, all major political figures, especially the government and state officials, must be completely subject to the rule of law that protects individual freedom and people's lives. Fourth, there must be a state bureaucracy that can be utilized by the new democratic government. Fifth, there must be an institutionalized economic society. Creating space for the development of society is impossible if democratic practices are still given or are state-centric. 
This paper wants to examine how the possibility of democratic consolidation is built by using local cultural values. Therefore, the perspective of democracy in Indonesia today must be rooted in the values of the locality. Local context democracy [1]is not meant to ignore the current democratic order and not to neglect the role of the state. Therefore, Santoso tried to compose a local contextual democracy that was directed at the lens of the culprit, namely 'citizenship' [1]. The starting point in this section is citizens as the main actors. Citizenship referred to in this section are citizens who have broader opportunities to freely express no-frills citizens who can be labeled with CSOs or civil society organizations (CSOs) that can be used as partners in which citizenship becomes a liaison occurs when the state still weak in providing political goods to facilitate what is already the needs of every citizen.

Majanggut I Village is an area of the Royal District of West Pakpak Regency. Majanggut I village itself consists of four hamlets namely Natam Jehe hamlet, Natam Julu hamlet, Kuta hamlet, and Kuta Batu hamlet. The area of the royal village is $15.40 \mathrm{Km}^{2}$ with a population of 938 people. If seen in terms of ethnic identity, the majority of Majanggut I villagers are from the Simsim tribe. In terms of religion, the majority of Majanggut I villagers embraced Christianity and some embraced Islam. Agriculture is the main livelihood of the people of Majanggut I village.

The peace of the Majanggut I noble village was disturbed when the village head elections were held simultaneously on October 24, 2018. The election of the village head of Majanggut I was attended by 4 pairs of candidates for village heads namely Merson Jobel Solin, Marie Solin, Tony Berutu, and Cipto Aceh. The initial confusion in the election of the village head Majanggut I began with the process of registering the village head election in which one partner, Tony Berutu, included the identity of the village head on the registration form. This made the P2KD committee (Village Head Election Committee) immediately annual the registration file of one of the candidate pairs of village head candidates.

Tony Berutu as the disallowed candidate pair was dissatisfied when their political rights were ignored because the P2KD did not provide time to fix the registration form file. For the head of the P2KD Majanggut I village, Hasmer Sitanggang, the reason for the alienation of one of the pairs of candidates for the village head was an incorrect registration form file and the lack of time to correct the registration form. The following are excerpts from the interview with the head of the P2KD Majanggut I village, recorded on October 24, 2019.

"There was an administrative error in registering one candidate for the village head. He (Tony Berutu) should have listed the village head candidate instead of the village head. We do not have time to correct the form following the technical guidelines from the local government).

The village head election committee remained adamant that one of the candidate pairs could not take part in the village head election and the village head election was carried out according to a predetermined schedule and resulted that Merson Jobel Solin was the winner in the village head election with a recapitulation of $76 \%$ of votes. The problem of the Majanggut I village head did not stop, after Merson Jobel Solin was elected village head, it turned out that he had not been inaugurated for six months. One of the clauses for delaying the inauguration of the elected village head was due to a lawsuit addressed to P2KD to the Medan PTUN on September 9, 2018, by Tony Berutu and Cipto Aceh. The Pakpak district government assumed that it was still waiting for the Medan Administrative Court decision because the Administrative Court granted the Tony Berutu and Cipto Aceh lawsuit to revoke the P2KD decision in holding the village head election. 
On the other hand, the elected head argues that the elected village head must be appointed because the lawsuit does not correlate with the results of the village head election because the one being sued is the P2KD in selecting the village head candidates and not the results of the village head election. It was on this basis that the villagers came to the Pakpak Regent's office to hold a demonstration and this was where the incident occurred, where the villagers argued and had physical contact with the security forces.

After waiting for the results of the Medan PTUN which said inkrah and the absence of a 14day appeal by the plaintiff, finally on 29 August 2019 the elected village head Merson Solin was appointed by PJ Regent Pakpak Bharat. What is interesting about this finding is not how the village head election process is concerned, but far from that the problems in Majanggut I village left some important questions. First, understanding how villagers understand democratic practices. Second, is the understanding of the village community regarding democratic institutions that are still categorized as low.

Theoretically, this research has not yet brought up the theory variant of the efforts to consolidate democracy by using a democratic model by prioritizing locality values, especially those in North Sumatra. A new perspective is needed to see democracy in Majanggut I village without destroying the democratic order that has been running with a locality-based democracy approach. Local-based democracy exists to provide a great opportunity for every citizen who has different identities to show their existence in the life of the state.

The case for the election of village heads in Majanggut I village illustrates that it is deemed necessary to review the meaning of democracy in every region of Indonesia which has its characteristics. Majanggut I village has the opportunity to involve local values in democratic practices. However, the biggest obstacle that must be faced by rural communities is an understanding of how the nature of the democratic practice itself can be integrated with existing locality values. Majanggut I community's understanding of how democratic practices are still far from what we imagine. As one resource person said, people only understand that democracy is only limited to elections. The following are excerpts of interviews with informants on behalf of Kammit Berutu.

"What we understand about democracy is the village head election, the election of the regent, governor, president, legislature. That's all if we don't know the others ... "

The interview passage above illustrates that the people of Majanggut I village are still categorized as passive and tend to be objects of democracy. The factor of education, the economy can be a trigger why they have limitations in that regard, but the state (district government) should be quick to anticipate how democratic practices should put village people as the main actors in the practice of democracy in the village. In the political aspect of citizenship, the chaos in the election of Majanggut I village heads in two aspects. First, the occurrence of mal procedure carried out by the P2KD committee in the selection of candidates for village heads. If referring to Pakpak Bharat Regency Regulation Number 8 of 2008 concerning procedures for nominating, Election, Inauguration, and Dismissal of Village Heads in Chapter II section 3 of article 8, it is stated that the task of the P2KD is to examine the identity of prospective candidates based on the specified requirements. In this section, the P2KD committee should examine the requirements file of the prospective village head carefully. If it is found that the requirements of one of the village head 
candidates are incomplete, this is where the $\mathrm{P} 2 \mathrm{KD}$ revised to return the village head candidate's requirements file. However, the $\mathrm{P} 2 \mathrm{KD}$ at that time argued that the regent's regulation did not explain the provision, even though Article 9 of the Pakpak Bharat Regent's regulation also indicated that the P2KD had the authority to resolve problems arising in the election of village heads.

The suspicion that arises from this event is the occurrence of an affair between one of the pairs of candidates for the village head and P2KD. In the practice of citizenship politics, this is a taboo thing to do. The people of Majanggut I village who have strong kinship values turned out to be unable to resolve administrative issues that could be resolved by the community itself. Second is the fading of locality values in Pakpak Bharat. Sukut Nitalu (are locality values owned by Majanggut I villagers) owned by Majanggut I villagers. Sukut Nitalu is values that contain together where various kinds of problems starting from family problems to village government issues can be resolved together. Sukut Nitalu will give birth to a Pertaki (adat head) who is elected together with the people of the village of Majanggut I. It is this Pertaki that has a big role if various issues arise in the government system. However, at present Pertaki does not have a large enough role as a mediator to solve problems that arise. Ideally, the values of locality in Sukut Nitalu can be adopted in democratic practices when rural communities are deadlocked to resolve turbulent conflicts when political contestation is held in the village.

One of the waning values of Sukut Nitalu is that Pertaki is also involved in practical political activities at the village level which causes the villagers' legitimacy towards Pertaki to be increasingly low. Borrowing the argument developed by Santoso and Nuruddin Al Akbar [1], ideally, citizens are active citizens or so-called (demos), who are sensitive or are always called to involve themselves in public affairs. However, that hasn't happened completely. The participation of villagers to become demos is precisely due to many reasons, it could be because of the arrogance of the politics of identity that flies, the politics of religious identity, and even political participation arises through vote-buying.

\section{Conclusion}

Local cultural values that exist in Majanggut I Village are no longer able to be a bond of togetherness to eat democracy. Citizens are trapped in the euphoria of democracy which is understood differently by people who have a diversity of cultures, ethnicities, and religions because democracy that is developing at this time can be said to be given through state-centric mechanisms. A new perspective is needed to see democracy in Majanggut I Village without destroying the democratic order that has been running with a locality-based democracy approach. Local based democracy exists to provide a great opportunity for every citizen who has different identities to show their existence in the life of the state.

\section{References}

[1] L. N. Bayo, P. Santoso, and W. P. Samadhi, Rezim lokal di Indonesia: memaknai ulang demokrasi kita. Yayasan Pustaka Obor Indonesia, 2018.

[2] A. Savirani and O. Tonrquist, "Reclaming The State; Mengatasi Problem Demokrasi di Indonesia 
Pasca-Soeharto.” Yogyakarta: PolGov \& PCD Press, 2016.

[3] W. Kymlicka, "Multicultural citizenship," Citizsh. debates, pp. 167-188, 1998.

[4] B. Parekh, Rethinking Multiculturalism: Keberagaman Budaya dan Teori Politik. Penerbit Kansiius, 2008.

[5] E. Hiariej and K. Stokke, Politics of citizenship in Indonesia. Yayasan Pustaka Obor Indonesia, 2017.

[6] S. Amin et al., Citizenship in Indonesia: Perjuangan atas Hak, Identitas, dan Partisipasi. Yayasan Pustaka Obor Indonesia, 2019. 